\title{
Quantitative differentiation of phenolic compounds in different varieties of buckwheat cultivars from China, Japan and Korea
}

\author{
Jeong Min Seo ${ }^{1}$, Da Bin Lee ${ }^{1}$, Mariadhas Valan Arasu' ${ }^{1}, \mathrm{Qi} \mathrm{Wu}^{2}$, Tatsuro Suzuki ${ }^{3}$, \\ Young-Ho Yoon ${ }^{4}$, Sang-Won Lee ${ }^{5}$, Sang Un Park ${ }^{6}$, Sun-Ju Kim ${ }^{1 *}$ \\ ${ }^{1}$ Department of Bio-Environmental Chemistry, Chungnam National University, Daejeon, South Korea; \\ *Corresponding Author: kimsunju@,cnu.ac.kr \\ ${ }^{2}$ Department of Life Sciences, Sichuan Agricultural University, Ya'an, China \\ ${ }^{3}$ National Agriculture and Food Research Organization, Hokkaido Agricultural Research Center, Sapporo, Japan \\ ${ }^{4}$ Highland Agriculture Research Center, National Institute of Crop Science, Rural Development Administration (RDA), Pyeongchang, \\ South Korea \\ ${ }^{5}$ Herbal Crop Utilization Research Team, National Institute of Horticultural \& Herbal Science, RDA, Eumseong, South Korea \\ ${ }^{6}$ Department of Crop Science, Chungnam National University, Daejeon, South Korea
}

Received 30 August 2013; revised 7 October 2013; accepted 15 October 2013

Copyright (C) 2013 Jeong Min Seo et al. This is an open access article distributed under the Creative Commons Attribution License, which permits unrestricted use, distribution, and reproduction in any medium, provided the original work is properly cited.

\section{ABSTRACT}

The aim of this study was to determine the variation of phenolic compounds in common and tartary buckwheats collected from China, Japan and Korea. Two buckwheat varieties of each country were cultivated using nutrient solution and vermiculite in the greenhouse from February to May, 2012 and harvested at twoweek intervals. Phenolics such as chlorogenic acid, C-glycosylflavones (orientin, isoorientin, vitexin, and isovitexin), rutin, and quercetin were quantified using high performance liquid chromatography (HPLC). At 17, 29, 44, 58, and 72 days after sowing (DAS), before harvesting each organs, rutin content of cultivars from China and Korea at 17 DAS was the highest (mean 43.63 and $39.95 \mathrm{mg} \cdot \mathrm{g}^{-1} \mathrm{DW}$, respectively) than that of 29 and 44 DAS. However, two varieties from Japan at 44 DAS were documented maximum; whereas, the amount of rutin in "Hokkai T10" harvested at 44 DAS $\left(58.36 \mathrm{mg} \cdot \mathrm{g}^{-1} \mathrm{DW}\right)$ was the highest of all cultivars. Rutin level in the leaves and stems at 72 DAS were comparatively higher than at 58 DAS. The highest of rutin content was found at 72 DAS $\left(73.33 \mathrm{mg} \cdot \mathrm{g}^{-1} \mathrm{DW}\right)$ in "Hokkai T10" leaves followed by "Daegwan

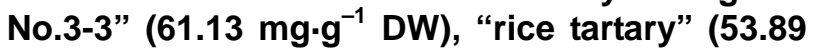
$\mathrm{mg} \cdot \mathrm{g}^{-1}$ DW). Rutin content of flowers was presented as the highest amount in "Hokkai T10" at
72 DAS (88.3 $\left.\mathrm{mg} \cdot \mathrm{g}^{-1} \mathrm{DW}\right)$ was approximately 14-fold higher than that of 58 DAS $\left(6.44 \mathrm{mg} \cdot \mathrm{g}^{-1}\right.$ DW). However, rutin content of flower in "Xiqiao No.2" was 3-fold higher at 72 DAS than at 58 DAS. Rutin and total phenolic compounds content in flowers, leaves, and stems were higher in the order. The content of four $C$-glycosylflavones in common buckwheat was higher than those in tartary buckwheat, but rutin content which accounted $>90 \%$ of the total phenolic compounds was higher in tartary buckwheat. The highest amounts of chlorogenic acid and quercetin were measured in the flower of "Xiqiao No.2" (6.85 and $11.69 \mathrm{mg} \cdot \mathrm{g}^{-1} \mathrm{DW}$, respectively). Based on these results, the presence of different phenolic compounds in all the varieties of buckwheat confirmed that it can be regarded as a potent source of functional foods.

Keywords: Buckwheat; Phenolic Compounds; Rutin; Functional Food

\section{INTRODUCTION}

Buckwheat (Fagopyrum esculentum) belonging to the family Polygonaceae which is originated from China, Korea, and Japan, has been commonly used as a vegetable in arid and cold regions in the world. It has been consumed in the form of groats, flour and noodles. How- 
ever, in Korea, Japan, Italy, and China, people eat buckwheat mainly in the form of noodles. Buckwheat seeds are richer in protein and antioxidant compounds such as phenolic compounds compared with rice and wheat [1]. The protein present in the buckwheat improves human health in various ways, notably reducing serum cholesterol [2] and suppressing gallstones and tumors [3]. Buckwheat possesses both antioxidant and antidiabetic activities which is attributed to its phenolic contents like rutin and quercetin [4]. This plant is considered as a functional food because of its high contents of phenolic compounds including rutin, quercetin, orientin, vitexin, isovitexein, and isoorientin [5]. Among these compounds, rutin, a flavonol glycoside, has been considered as a major antioxidant component that accounts $85 \%-90 \%$ of the total anti-oxidant activity [6]. Rutin is also known to have anti-inflammatory, anti-carcinogenic effects and is used for preventing hemorrhagic disease and arteriosclerosis [7,8]. Likewise, quercetin (aglycone), a major bioflavonoid of human diet, has been identified as a strong anti-oxidant, anti-angiogenesis, and anti-cancer [9]. It is also known to reduce the risk of hypertension [10]. Besides rutin and quercetin, the other flavonoids like vitexin, isovitexin, orientin, and isoorientin are also considered as good anti-oxidant compounds present in buckwheat and have been reported to exhibit 4\% - 40\% of anti-oxidant activities [11,12]. Vitexin has been found to be effective in the prevention of skin cell damage caused by UV- radiation [13]. Orientin has the ability to protect liver from carcinogens and radiations and isoorientin is known to scavenge free radicals and prevent human LDL (low density lipoprotein) against oxidation [14].

Scientists and nutritionists are interested in making use of functional vegetables to increase the health benefits they provide to the body by cultivation and breeding technology [15]. For example, to prepare cereal-type sprouts, germination time is generally less than $24 \mathrm{~h}$, as this will achieve a softer texture by cell-wall degradation and improve the taste due to an increase in sugar. It is expected that in the future, cereal-type sprouts will undergo more improvements to their functional constituents than cereals. In germinated barley, it has been reported that the antioxidant activity is higher than that of nongerminated barley [16]. In germinated brown rice, it has been reported that there is 10 times more GABA $(\gamma$ aminobutyric acid), which has an antihypertensive effect, as compared to non-germinated brown rice [17]. Vegetable-type sprouts usually contain quantities of beneficial carbohydrates, proteins, amino acids, vitamins, minerals, and phenolic compounds that are found in higher abundance when compared to mature vegetables or dormant seeds [18]. In soybean sprouts, it has been reported that the content of phenolic compounds and isoflavones is higher than that of soybeans $[18,19]$. In lentil sprouts, it has been reported that vitamin $\mathrm{C}$ and total phenols are three times higher than that of seeds [20].

In this paper, we measured and compared the beneficial functional components in different buckwheat cultivars grown at China, Japan, and Korea. We determined individual phenolic compounds including rutin during the cultivation periods by high performance liquid chromatography (HPLC) analysis.

\section{MATERIALS AND METHODS}

\subsection{Chemicals}

HPLC grade acetonitrile $\left(\mathrm{CH}_{3} \mathrm{CN}\right)$ and methanol $(\mathrm{MeOH})$ were purchased from Wako Pure Chemical Industries (Osaka, Japan). Authentic compounds such as chlorogenic acid and flavonoids including $C$-glycosylflavones (orientin, isoorientin, vitexin, and isovitexin), rutin, and quercetin were supplied by Extrasynthese (Genay, France) for external standards.

\subsection{Plant Materials and Cultivation}

Cultivars such as "Dawon" and "Daegwan No.3-3" were provided from Rural Development Administration (RDA) in Korea, "Kitawase", and "Hokkai T10" was obtained from Hokkaido Agricultural Research Center (HARC) in Japan. "Xiqiao No.2" and "rice tartary" were kind gift from China Xichang Agricultural College. Among them, "rice tartary", "Xiqiao No.2", "Daegwan No.3-3" and "Hokkai T10" were tartary buckwheat ( $F a$ gopyrum tataricum Gaertn.), and the others were common buckwheat ( $F$. esculentum Moench). Two buckwheat varieties of each country were cultivated in vermiculite together with nutrient solution in the greenhouse at Chungnam National University from February to May, 2012 and harvested at two-week intervals. The composition of the nutrient solution was as follows: [macro elements (basically N-P-K 10-1-5 mM): $\mathrm{KCl} 5 \mathrm{mmol} \cdot \mathrm{L}^{-1}$, $\mathrm{Ca}\left(\mathrm{NO}_{3}\right)_{2} \cdot 4 \mathrm{H}_{2} \mathrm{O} 2 \mathrm{mmol} \cdot \mathrm{L}^{-1} ; \mathrm{NH}_{4} \mathrm{NO}_{3} 2.5 \mathrm{mmol} \cdot \mathrm{L}^{-1}$, $\mathrm{NH}_{4} \mathrm{H}_{2} \mathrm{PO}_{4} 1 \mathrm{mmol} \cdot \mathrm{L}^{-1}, \mathrm{MgSO}_{4} \cdot 7 \mathrm{H}_{2} \mathrm{O} 1 \mathrm{mmol} \cdot \mathrm{L}^{-1}$; micro elements: $\mathrm{MnCl}_{2} \cdot 4 \mathrm{H}_{2} \mathrm{O} 1.801 \mathrm{~g} \cdot \mathrm{L}^{-1}, \mathrm{H}_{3} \mathrm{BO}_{3} 2.86$ $\mathrm{g} \cdot \mathrm{L}^{-1}, \mathrm{ZnSO}_{4} \cdot 7 \mathrm{H}_{2} \mathrm{O} \quad 0.222 \mathrm{~g} \cdot \mathrm{L}^{-1},\left(\mathrm{NH}_{4}\right)_{6} \mathrm{Mo}_{7} \mathrm{O}_{24} \cdot 4 \mathrm{H}_{2} \mathrm{O}$ $0.092 \mathrm{~g} \cdot \mathrm{L}^{-1}, \mathrm{CuSO}_{4} \cdot 5 \mathrm{H}_{2} \mathrm{O} 0.0785 \mathrm{~g} \cdot \mathrm{L}^{-1}, \mathrm{Fe}-$ EDTA 22.62 $\left.\mathrm{g} \cdot \mathrm{L}^{-1}\right]$ according to the Japanese Enshi-type solutions. Buckwheat seeds were sown in 72 cell flug tray in the greenhouse at Chungnam national University. After 15 days after sowing (DAS) (March 6, 2012), explants were transferred and transplanted (two replicates per each cultivars $)$ into plastic pots $(50 \times 20 \times 18 \mathrm{~cm})$ containing 3.6 $\mathrm{kg}$ vermiculite and incubated at green house. Some of the seedlings of all cultivars were harvested at 17 DAS one day later. After one week from transplanting into the vermiculate, nutrient solution were sprayed by diluting the appropriate concentration according to Japan horticultural test composition. The temperature (average 
$\left.24.1^{\circ} \mathrm{C}\right)$, humidity $(14.3 \%)$ and light intensity (375 $\mu \mathrm{mol} / \mathrm{m}^{2} \mathrm{~s}$ ) were monitored regularly. A total cultivation period was 72 days. After transplantation, plants were harvested total of four times at two-week intervals. At 58 and 72 DAS buckwheats were separated according to the organs (leaves, stems, and flowers). At all harvest times $(17,29,44,58$, and 72 DAS), the roots of buckwheats were harvested by cutting with scissors, to analyze phenolic compounds, plants harvested only at 58 and 72 DAS were classified as leaves, stems and flowers. Samples were rapidly kept in $-70^{\circ} \mathrm{C}$ ultra low temperature freezer (SFDSF 12, Samwon Freezing Engineering Co., Busan, Korea) for freeze-drying. After freeze drying, samples were weighted their dry weight (DW), ground with blender together with mortar and pestle, and individually stored in desiccator until chemical analysis.

\subsection{Extraction and Quantification of Phenolic Compounds}

A $10 \mathrm{mg}$ portion of the lyophilized powder was transferred into $1 \mathrm{~mL} \mathrm{MeOH}$ containing 10\% phosphoric acid $[0.1 \%(v / v)]$ in a $2-\mathrm{mL}$ eppendorf tube. Briefly, the solution was vigorously vortexed for $5 \mathrm{~min}$, and incubated at $37^{\circ} \mathrm{C}$ for $3 \mathrm{~h}$ and then centrifuged at $12,000 \mathrm{rpm}$ for 5 min. The extract was filtered through a $0.45 \mu \mathrm{m}$ PTFE syringe filter (Advantec DISMIC-13HP, Toyo Roshi Kaisha, Ltd., Tokyo, Japan). The filtrate was then analyzed by Perkin Elmer Flexar (PerkinElmer Inc., Shelton, CT) equipped with variable wavelength detector. The data were recorded with a Compaq Presario CQ3100KL computer (Samsung, South Korea) and analyzed by Chromera software.

The chromatographic separation was performed on Capcell PAK C18 column $(250 \times 4.6 \mathrm{~mm}$, i.d., particle size $5 \mu \mathrm{m}$; Shiseido, Tokyo, Japan). Detection was made at a wavelength of $350 \mathrm{~nm}$, and the column oven temperature was set at $40^{\circ} \mathrm{C}$. The injection volume was 10 $\mu \mathrm{L}$. The solvent system was delivered at a rate of 1.0 $\mathrm{mL} \cdot \mathrm{min}^{-1}$ and consisted of a mixture of (A) MeOH:water:acetic acid (5:92.5:2.5, v/v/v) and (B) $\mathrm{MeOH}$ : water: acetic acid $(95: 2.5: 2.5, v / v / v)$. The gradient program used as follows: $0 \mathrm{~min}, 10 \% \mathrm{~B}$; $0-27 \mathrm{~min}, 36 \% \mathrm{~B} ; 27-32$ $\min , 60 \% \mathrm{~B} ; 32-35 \mathrm{~min}, 60 \% \mathrm{~B} ; 35-35.1 \mathrm{~min}, 10 \% \mathrm{~B}$; 35.1 - $40 \mathrm{~min}, 10 \% \mathrm{~B}$. For the quantification of individual phenolic compounds by external standard method, each authentic standard was separately injected into HPLC. Then, the quantification of the different compounds was performed by directly comparing the peak areas of standard and sample and calculated as equivalents of representative standard compounds. All contents were expressed as milligram per $\mathrm{g} D \mathrm{DW}$.

\subsection{Statistical Analysis}

Data were analyzed by application of the Tukey's mul- tiple range test at $\mathrm{P} \leq 0.05$, using SPSS statistical software (version 11.5 for Windows, SPPS Inc., Chicago, IL, USA). The data shown in all Tables are the means of two replicates. For comparisons of continuous parameters between groups and within a group over time, repeated measures ANOVA was used.

\section{RESULTS AND DISCUSSION}

The total phenolic content in two cultivars of buckwheats grown in Korea, Japan and China was determined. Phenolic compounds such as chlorogenic acid, $C$-glycosylflavones (orientin, isoorientin, vitexin, and isovitexin), rutin, and quercetin were identified in common and tartary buckwheats (Figure 1(a)) and quantified by comparing with their commercial standards and expressed as milligram per $\mathrm{g} D \mathrm{DW}$. The results revealed that the total phenolic content of tartary buckwheat seedlings was comparatively higher than that of the common buckwheat in all the other types of vegetables studied in the research (Table 1). The total phenolic compounds ranged from $16.11-28.86 \mathrm{mg} \cdot \mathrm{g}^{-1} \mathrm{DW}$ in common buckwheats and $24.15-62.15 \mathrm{mg} \cdot \mathrm{g}^{-1} \mathrm{DW}$ in the varieties of tartary buckwheat harvested after 29 and 44 DAS. Among the tartary buckwheat, "Hokkai T10" documented highest total phenolic compounds $\left(62.15 \mathrm{mg} \cdot \mathrm{g}^{-1} \mathrm{DW}\right)$ followed by "Xiqiao No.2" noticed ( $49.51 \mathrm{mg} \cdot \mathrm{g}^{-1} \mathrm{DW}$ ) about $40 \%$ higher than common buckwheats. These results were comparatively better in good accordance with some previously reported data; e.g. Zielinski et al. (1998) [21] found total phenolics in dehulled buckwheat $\left(269 \mathrm{mg} \cdot 100 \mathrm{~g}^{-1}\right)$, although Zielinski and Troszynska (2000) [22] showed a range from 164.7 to $408.2 \mathrm{mg} \cdot 100 \mathrm{~g}^{-1}$. Tahir and Farooq (1985) [23] analyzed the buckwheat variety-dependence of polyphenol content and found that the total phenolic content varied from 770 to $1660 \mathrm{mg} \cdot 100 \mathrm{~g}^{-1}$ dry matter, depending on the variety.

Rutin determined in the edible portions of "Dawon" seedlings increased linearly during plant growth at 17 44 DAS (Table 1). Approximately $90 \%$ of total phenolic content were contributed by rutin in common and tartary buckwheats. In the edible portions of "Hokkai T10" seedlings, rutin content was significantly greater (58.36 $\mathrm{mg} \cdot \mathrm{g}^{-1} \mathrm{DW}$ ) at 44 DAS than at any earlier date, while, conversely, rutin content in the "rice tartary" and "Daegwan No.3-3" was significantly higher (43.63 and 39.95 $\mathrm{mg} \cdot \mathrm{g}^{-1} \mathrm{DW}$, respectively) at 17 DAS than any day thereafter. Rutin content in common buckwheat was also marginally similar to tartary buckwheat. Among the common buckwheats, "Kitawase" and "Dawon" produced maximum 19.54 and $26.55 \mathrm{mg} \mathrm{g}^{-1} \mathrm{DW}$ at 29 and 44 DAS, respectively (Figure 1(b)).

Variation of phenolic compounds (rutin, vitexin, isovitexin, orientin, isoorientin, quercetin, and chlorogenic acid) in common and tartary buckwheat was analyzed 


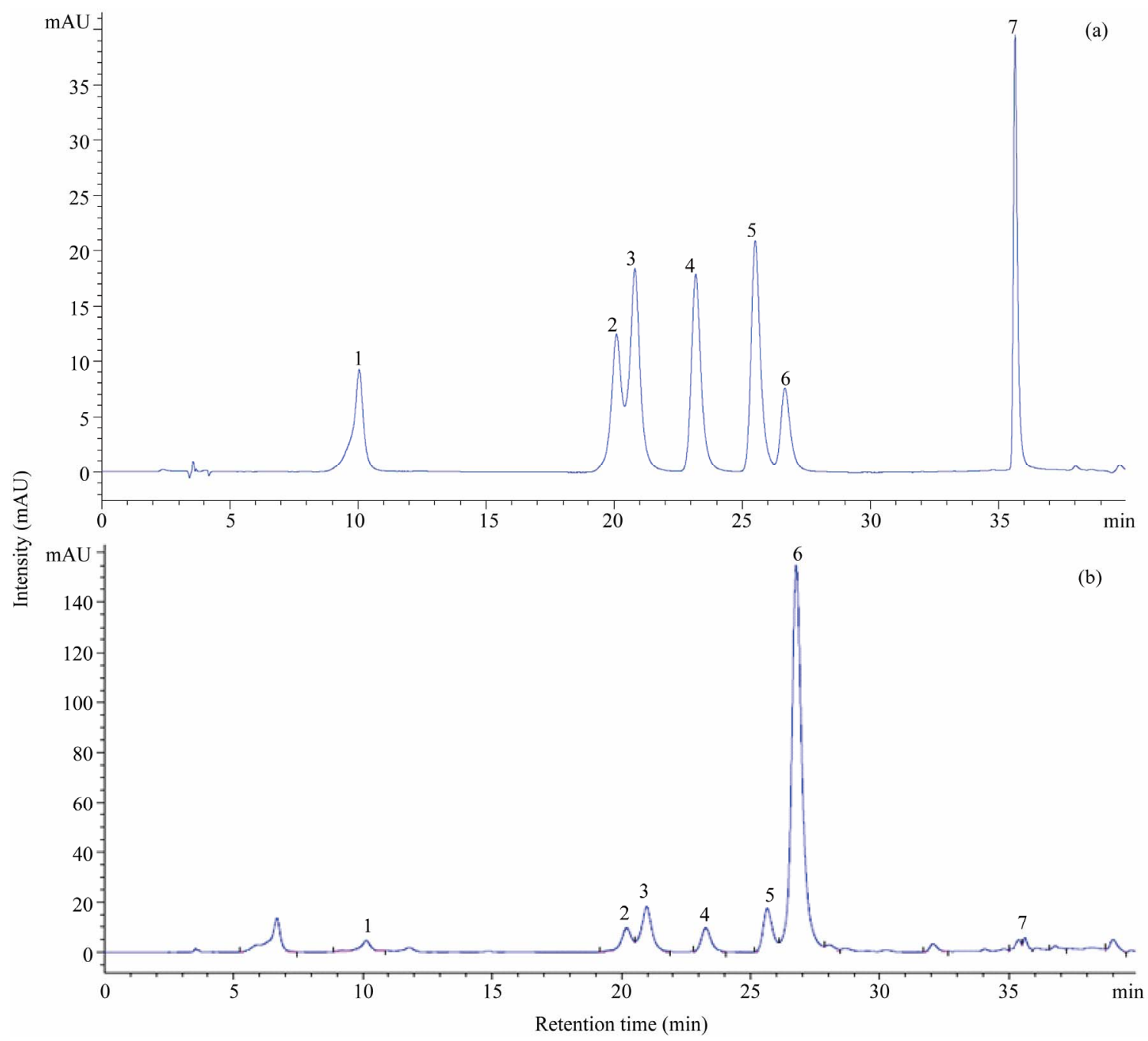

Figure 1. HPLC chromatogram of phenolic compounds. (a), seven standards of phenolic compounds; (b) 'Kitawase' at 29 DAS. Peak numbers refer to the phenolic compounds listed in Table 1: 1, chlorogenic acid; 2, orientin; 3, isoorientin; 4 , vitexin; 5 , isovitexin; 6 , rutin; 7 , quercetin.

after 58 and 78 DAS (Table 2). The results showed that the rutin was present in highest amount in all tartary buckwheats. Rutin content of "Hokkai T10" at 72 DAS was $73.33,88.33$, and $9.20 \mathrm{mg} \cdot \mathrm{g}^{-1} \mathrm{DW}$ in leaf, flower, and stem, respectively. Similar trend was also observed in common buckwheat such as "Kitawase" and "Dawon" for quercetin contents; however, their contents were comparatively lower than tartary buckwheat (Table 2). Orientin, isoorientin, vitexin, and isovitexin were found at very low levels in the leaf and stem of "Kitawase" and "Dawon" and completely absent in stem except isovitexin (Table 2). In common buckwheat, the highest rutin content was found in the flower of "Dawon" $\left(47.75 \mathrm{mg} \cdot \mathrm{g}^{-1}\right.$ DW) at 72 DAS of cultivation followed by the leaf and stem (32.29 and $5.22 \mathrm{mg} \cdot \mathrm{g}^{-1} \mathrm{DW}$, respectively). A good amount (11.69 $\left.\mathrm{mg} \cdot \mathrm{g}^{-1} \mathrm{DW}\right)$ of quercetin was detected in the flower of "Xiqiao No.2" but it was observed less amount in the stem and leaf. Whereas, quercetin was not detected in "Kitawase" and "rice tartary" stem portion.

Oomah and Mazza (1996) [24] reported the variability in the phenolic content of buckwheat due to difference in cultivar, cultivation time, and cultivation location. Coincides with this report, our results revealed variations in total and individual phenolic compounds. Significant difference was observed between common and tartary buckwheat. Similar to this result, Park et al. (2004) [25] also reported significant variation in rutin content in the tartary buckwheat cultivars from different regions. In our study, we observed that the total phenolic content of the leaf, flower, and stem of tartary buckwheat were varied and comparatively higher than those of the common varieties. In case of tartary buckwheat, the content of some compounds like rutin and quercetin in leaf, flower and stem was much higher than common buckwheat, as reported by Kim et al. (2008) [11]. Whereas, vitexin, iso- 
Table 1. Phenolic compounds $\left(\mathrm{mg} \cdot \mathrm{g}^{-1} \mathrm{DW}\right)^{\mathrm{a}}$ in buckwheat seedlings $\mathrm{s}^{\mathrm{b}}$ and harvested at 29 and 44 DAS.

\begin{tabular}{|c|c|c|c|c|c|c|c|c|c|c|}
\hline Species & $\mathrm{DAS}^{\mathrm{c}}$ & Cultivars & $\begin{array}{l}\text { Chlorogenic } \\
\text { acid }\end{array}$ & Orientin & Isoorientin & Vitexin & Isovitexin & Rutin & Quercetin & Total \\
\hline \multirow[t]{6}{*}{ Common $^{\mathrm{d}}$} & 17 & Kitawase & $1.03 \pm 0.04$ & $7.80 \pm 0.17$ & $10.09 \pm 0.21$ & $3.42 \pm 0.07$ & $5.54 \pm 0.12$ & $7.62 \pm 0.16$ & $0.47 \pm 0.02$ & $35.96 \pm 0.79$ \\
\hline & & Dawon & $1.12 \pm 0.08$ & $6.41 \pm 0.31$ & $8.04 \pm 0.39$ & $3.03 \pm 0.15$ & $4.87 \pm 0.24$ & $8.15 \pm 0.48$ & $\mathrm{ND}^{\mathrm{e}}$ & $31.62 \pm 1.65$ \\
\hline & 29 & Kitawase & $0.71 \pm 0.06$ & $1.17 \pm 0.00$ & $1.42 \pm 0.00$ & $0.68 \pm 0.00$ & $1.12 \pm 0.00$ & $19.54 \pm 0.00$ & $0.18 \pm 0.00$ & $24.82 \pm 0.08$ \\
\hline & & Dawon & $0.68 \pm 0.00$ & $2.14 \pm 0.05$ & $2.76 \pm 0.07$ & $2.08 \pm 0.05$ & $3.39 \pm 0.08$ & $11.75 \pm 0.18$ & $0.17 \pm 0.00$ & $22.97 \pm 0.44$ \\
\hline & 44 & Kitawase & $0.78 \pm 0.26$ & ND & $0.21 \pm 0.00$ & ND & ND & $15.09 \pm 1.23$ & $0.14 \pm 0.01$ & $16.11 \pm 0.84$ \\
\hline & & Dawon & $1.93 \pm 1.40$ & $0.23 \pm 0.00$ & ND & ND & ND & $26.55 \pm 15.80$ & $0.27 \pm 0.29$ & $28.86 \pm 17.64$ \\
\hline \multirow[t]{12}{*}{ Tartary } & 17 & $\begin{array}{l}\text { Rice } \\
\text { Tartary }\end{array}$ & $2.20 \pm 0.01 b$ & $0.32 \pm 0.01 b$ & $0.20 \pm 0.00 \mathrm{c}$ & $0.74 \pm 0.00 \mathrm{bc}$ & $1.01 \pm 0.00 \mathrm{c}$ & $43.63 \pm 0.04 a$ & $0.13 \pm 0.00 \mathrm{a}$ & $48.23 \pm 0.04 a$ \\
\hline & & Xiqiao No.2 & $2.26 \pm 0.07 b$ & $0.84 \pm 0.03 a$ & $1.01 \pm 0.04 \mathrm{a}$ & $1.23 \pm 0.04 \mathrm{a}$ & $1.83 \pm 0.06 \mathrm{a}$ & $42.07 \pm 1.57 \mathrm{ab}$ & $0.27 \pm 0.00 \mathrm{a}$ & $49.51 \pm 1.81 \mathrm{a}$ \\
\hline & & Hokkai T10 & $2.28 \pm 0.10 b$ & $0.46 \pm 0.01 b$ & ND & $0.73 \pm 0.01 \mathrm{c}$ & $0.58 \pm 0.02 \mathrm{~d}$ & $37.10 \pm 1.05 b$ & $0.85 \pm 0.02 \mathrm{a}$ & $42.00 \pm 1.19 \mathrm{a}$ \\
\hline & & $\begin{array}{c}\text { Daegwan } \\
\text { No.3-3 }\end{array}$ & $2.61 \pm 0.00 \mathrm{a}$ & $0.35 \pm 0.08 b$ & $0.36 \pm 0.03 b$ & $0.90 \pm 0.06 \mathrm{~b}$ & $1.25 \pm 0.07 \mathrm{~b}$ & $39.95 \pm 2.36 \mathrm{ab}$ & $0.49 \pm 0.43 a$ & $45.91 \pm 3.03 a$ \\
\hline & 29 & $\begin{array}{l}\text { Rice } \\
\text { Tartary }\end{array}$ & $2.92 \pm 0.07 \mathrm{ab}$ & $0.32 \pm 0.01 b$ & ND & $0.14 \pm 0.00 \mathrm{a}$ & $0.14 \pm 0.00 \mathrm{~b}$ & $23.50 \pm 0.51 \mathrm{c}$ & $\begin{array}{l}0.15 \pm \\
0.01 b c\end{array}$ & $27.09 \pm 0.68 \mathrm{c}$ \\
\hline & & Xiqiao No.2 & $2.78 \pm 0.09 b$ & $0.20 \pm 0.01 \mathrm{c}$ & $\mathrm{ND}^{\mathrm{d}}$ & $0.18 \pm 0.00 \mathrm{a}$ & $0.19 \pm 0.00 \mathrm{a}$ & $20.71 \pm 0.66 \mathrm{~d}$ & $0.17 \pm 0.00 \mathrm{~b}$ & $24.15 \pm 0.88 \mathrm{c}$ \\
\hline & & Hokkai T10 & $3.22 \pm 0.05 a$ & $0.44 \pm 0.02 \mathrm{a}$ & ND & $0.19 \pm 0.01 \mathrm{a}$ & $0.14 \pm 0.00 \mathrm{~b}$ & $34.90 \pm 0.64 \mathrm{a}$ & $0.30 \pm 0.02 \mathrm{a}$ & $39.18 \pm 0.73 a$ \\
\hline & & $\begin{array}{c}\text { Daegwan } \\
\text { No.3-3 }\end{array}$ & $3.27 \pm 0.15 \mathrm{a}$ & $0.31 \pm 0.04 \mathrm{~b}$ & ND & $0.19 \pm 0.00 \mathrm{a}$ & $0.20 \pm 0.00 \mathrm{a}$ & $27.18 \pm 0.52 b$ & $0.11 \pm 0.00 \mathrm{c}$ & $31.27 \pm 0.63 b$ \\
\hline & 44 & $\begin{array}{l}\text { Rice } \\
\text { Tartary }\end{array}$ & $2.29 \pm 0.40 \mathrm{a}$ & $0.21 \pm 0.03 b$ & ND & ND & ND & $34.85 \pm 8.01 \mathrm{a}$ & $0.33 \pm 0.05 \mathrm{a}$ & $37.68 \pm 8.48 \mathrm{a}$ \\
\hline & & Xiqiao No.2 & $3.12 \pm 0.06 \mathrm{a}$ & ND & ND & ND & ND & $33.69 \pm 5.51 \mathrm{a}$ & $0.09 \pm 0.03 \mathrm{a}$ & $36.90 \pm 5.49 a$ \\
\hline & & Hokkai T10 & $2.65 \pm 0.09 a$ & $0.44 \pm 0.02 \mathrm{a}$ & ND & $0.19 \pm 0.01$ & ND & $58.36 \pm 4.96 \mathrm{a}$ & $0.52 \pm 0.06 \mathrm{a}$ & $62.15 \pm 5.12 \mathrm{a}$ \\
\hline & & $\begin{array}{l}\text { Daegwan } \\
\text { No.3-3 }\end{array}$ & $2.93 \pm 0.10 \mathrm{a}$ & $0.26 \pm 0.01 b$ & ND & ND & ND & $28.79 \pm 18.14 a$ & $0.35 \pm 0.29 a$ & $32.33 \pm 18.54 a$ \\
\hline
\end{tabular}

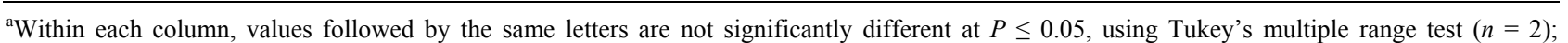
${ }^{\mathrm{b}}$ seedling; $17 \mathrm{DAS}$; ${ }^{\mathrm{C}} \mathrm{DAS}$; Days after sowing; ${ }^{\mathrm{d}}$ not performed Tukey's multiple range test because there are fewer than three groups; ${ }^{\mathrm{e}} \mathrm{ND}$., not detected.

vitexin were not detected. It was also noticeable in our research that the chlorogenic acid content in the flower of "Xiqiao No.2" at 58 DAS was much higher (10.24 $\left.\mathrm{mg} \cdot \mathrm{g}^{-1} \mathrm{DW}\right)$ compared to other tartary buckwheats.

According to the data (Table 1), vitexin, isovitexin, orientin, and isoorientin seemed to vary or decrease gradually in the common and tartary buckwheat. The functionality of buckwheat plants has been evaluated from the levels of rutin because of its anti-blood pressure effects (hypertension). This variation in the concentration of rutin among the different buckwheat could be due to the reasons such as genetic nature of buckwheat $[11,19]$.

The present study, variation of phenolic compounds in different varieties of buckwheat cultivated at Korea, Japan and China was studied. It was observed that, all the varieties of buckwheat could be used as a potent source of phenolics (chlorogenic acid, orientin, isoorientin, vitexin, isovitexin, rutin, and quercetin). If buckwheat is to be categorized as a functional food, it is important that it has the maximum amount of beneficial ingredients. It was observed that rutin represented about $90 \%$ of the total content of phenolic compounds in common and Tartary buckwheats.

\section{ACKNOWLEDGEMENTS}

This study was financially supported by research fund of Chungnam 
Table 2. Phenolic compounds $\left(\mathrm{mg} \mathrm{g}^{-1} \mathrm{DW}\right)^{\mathrm{a}}$ in buckwheat leaf, flower and stem harvested at 58 and 72 DAS.

\begin{tabular}{|c|c|c|c|c|c|c|c|c|c|c|c|}
\hline Species & Parts & $\mathrm{DAS}^{\mathrm{b}}$ & Cultivars & Chlorogenic acid & Orientin & Isoorientin & Vitexin & Isovitexin & Rutin & Quercetin & Total \\
\hline \multirow[t]{2}{*}{ Common $^{c}$} & Leaf & 58 & Kitawase & $0.06 \pm 0.07$ & $\begin{array}{c}0.29 \pm \\
0.05\end{array}$ & $0.40 \pm 0.04$ & $\begin{array}{c}0.16 \pm \\
0.09\end{array}$ & $0.32 \pm 0.08$ & $11.13 \pm 1.98$ & $0.12 \pm 0.04$ & $\begin{array}{c}12.48 \pm \\
2.09\end{array}$ \\
\hline & & & Dawon & $0.02 \pm 0.00$ & $\begin{array}{c}0.29 \pm \\
0.04\end{array}$ & $0.36 \pm 0.01$ & $\begin{array}{c}0.23 \pm \\
0.12\end{array}$ & $0.40 \pm 0.16$ & $15.93 \pm 1.35$ & $0.07 \pm 0.03$ & $\begin{array}{c}17.30 \pm \\
1.66\end{array}$ \\
\hline \multirow[t]{4}{*}{ Tartary } & & & $\begin{array}{l}\text { Rice } \\
\text { Tartary }\end{array}$ & $0.29 \pm 0.36 \mathrm{a}$ & $\mathrm{ND}^{\mathrm{d}}$ & ND & ND & ND & $\begin{array}{c}37.98 \pm \\
3.87 \mathrm{ab}\end{array}$ & $0.75 \pm 0.11 \mathrm{a}$ & $\begin{array}{l}39.02 \pm \\
4.34 \mathrm{ab}\end{array}$ \\
\hline & & & Xiqiao No.2 & $0.23 \pm 0.04 \mathrm{a}$ & ND & ND & ND & ND & $29.39 \pm 1.24 b$ & $0.52 \pm 0.24 \mathrm{a}$ & $\begin{array}{l}30.14 \pm \\
1.44 \mathrm{~b}\end{array}$ \\
\hline & & & Hokkai T10 & $0.18 \pm 0.15 \mathrm{a}$ & ND & ND & ND & ND & $52.13 \pm 6.45 a$ & $0.71 \pm 0.13 \mathrm{a}$ & $\begin{array}{c}53.02 \pm \\
6.43 \mathrm{a}\end{array}$ \\
\hline & & & Daegwan No.3-3 & $0.15 \pm 0.01 \mathrm{a}$ & ND & ND & ND & ND & $\begin{array}{l}41.50 \pm \\
3.35 \mathrm{ab}\end{array}$ & $0.65 \pm 0.02 \mathrm{a}$ & $\begin{array}{c}42.30 \pm \\
3.35 \mathrm{ab}\end{array}$ \\
\hline \multirow[t]{2}{*}{ Common } & Leaf & 72 & Kitawase & ND & $\begin{array}{c}0.23 \pm \\
0.08\end{array}$ & $0.28 \pm 0.07$ & $\begin{array}{c}0.03 \pm \\
0.02\end{array}$ & $0.15 \pm 0.03$ & $16.67 \pm 5.13$ & $0.09 \pm 0.04$ & $\begin{array}{c}17.45 \pm \\
5.32\end{array}$ \\
\hline & & & Dawon & $0.09 \pm 0.00$ & $\begin{array}{c}0.09 \pm \\
0.09\end{array}$ & $0.15 \pm 0.07$ & ND & $0.06 \pm 0.06$ & $32.29 \pm 12.39$ & $0.19 \pm 0.25$ & $\begin{array}{c}32.82 \pm \\
12.72\end{array}$ \\
\hline \multirow[t]{4}{*}{ Tartary } & & & $\begin{array}{l}\text { Rice } \\
\text { Tartary }\end{array}$ & ND & ND & ND & ND & ND & $53.89 \pm 7.52 \mathrm{ab}$ & $1.33 \pm 0.35 \mathrm{a}$ & $\begin{array}{l}55.22 \pm \\
7.17 \mathrm{ab}\end{array}$ \\
\hline & & & Xiqiao No.2 & $0.11 \pm 0.12 \mathrm{a}$ & ND & ND & ND & ND & $40.16 \pm 3.48 b$ & $0.47 \pm 0.09 b$ & $\begin{array}{c}40.73 \pm \\
3.69 \mathrm{~b}\end{array}$ \\
\hline & & & Hokkai T10 & $0.04 \pm 0.03 \mathrm{a}$ & ND & ND & ND & ND & $\begin{array}{c}73.33 \pm \\
10.20 \mathrm{a}\end{array}$ & $0.58 \pm 0.04 \mathrm{ab}$ & $\begin{array}{l}73.95 \pm \\
10.27 \mathrm{a}\end{array}$ \\
\hline & & & Daegwan No.3-3 & $0.12 \pm 0.01 \mathrm{a}$ & ND & ND & ND & ND & $\begin{array}{l}61.13 \pm \\
5.54 \mathrm{ab}\end{array}$ & $0.80 \pm 0.06 \mathrm{ab}$ & $\begin{array}{l}62.04 \pm \\
5.49 \mathrm{ab}\end{array}$ \\
\hline \multirow[t]{2}{*}{ Common } & Flower & 58 & Kitawase $^{e}$ & 9.27 & ND & ND & ND & 0.10 & 39.01 & 2.50 & 50.88 \\
\hline & & & Dawon $^{\mathrm{e}}$ & 7.18 & ND & ND & ND & ND & 33.22 & 1.00 & 41.40 \\
\hline \multirow[t]{4}{*}{ Tartary } & & & $\begin{array}{l}\text { Rice } \\
\text { Tartary }\end{array}$ & ND & ND & ND & ND & ND & ND & ND & ND \\
\hline & & & Xiqiao No.2 & $10.24 \pm 0.45$ & ND & ND & ND & ND & $30.86 \pm 1.02$ & $8.36 \pm 0.98$ & $\begin{array}{c}49.46 \pm \\
0.48\end{array}$ \\
\hline & & & Hokkai $\mathrm{T} 10^{\mathrm{e}}$ & 0.98 & ND & ND & ND & ND & 6.44 & 1.55 & 8.97 \\
\hline & & & $\begin{array}{c}\text { Daegwan } \\
\text { No.3-3 }{ }^{\mathrm{e}}\end{array}$ & 8.09 & ND & ND & ND & ND & 63.99 & 12.64 & 84.72 \\
\hline \multirow[t]{2}{*}{ Common } & Flower & 72 & Kitawase & $6.53 \pm 0.91$ & ND & ND & ND & $0.06 \pm 0.00$ & $33.72 \pm 9.86$ & $1.45 \pm 0.21$ & $\begin{array}{c}41.73 \pm \\
9.20\end{array}$ \\
\hline & & & Dawon & $6.00 \pm 2.05$ & $\begin{array}{c}0.02 \pm \\
0.01\end{array}$ & ND & ND & $0.08 \pm 0.11$ & $47.75 \pm 3.18$ & $0.93 \pm 0.66$ & $\begin{array}{c}54.78 \pm \\
5.80\end{array}$ \\
\hline \multirow[t]{4}{*}{ Tartary } & & & $\begin{array}{l}\text { Rice } \\
\text { Tartary }\end{array}$ & ND & ND & ND & ND & ND & ND & ND & ND \\
\hline & & & Xiqiao No.2 & $6.85 \pm 0.91$ & ND & ND & ND & ND & $76.40 \pm 10.28$ & $11.69 \pm 2.11$ & $\begin{array}{c}94.94 \pm \\
13.30\end{array}$ \\
\hline & & & Hokkai $\mathrm{T} 10^{\mathrm{e}}$ & 6.63 & ND & 0.13 & 0.31 & ND & 88.33 & 19.07 & 114.47 \\
\hline & & & $\begin{array}{c}\text { Daegwan } \\
\text { No.3-3 }{ }^{\mathrm{e}}\end{array}$ & 6.40 & ND & ND & ND & ND & 61.01 & 18.33 & 85.74 \\
\hline \multirow[t]{2}{*}{ Common } & Stem & 58 & Kitawase & $0.16 \pm 0.20$ & ND & ND & ND & $0.58 \pm 0.01$ & $2.57 \pm 0.03$ & ND & $3.31 \pm 0.22$ \\
\hline & & & Dawon & $0.57 \pm 0.14$ & ND & ND & ND & $0.96 \pm 0.17$ & $4.88 \pm 0.84$ & $0.03 \pm 0.01$ & $6.45 \pm 1.16$ \\
\hline
\end{tabular}




\section{Continued}

\begin{tabular}{|c|c|c|c|c|c|c|c|c|c|c|c|}
\hline \multirow[t]{4}{*}{ Tartary } & & & $\begin{array}{c}\text { Rice } \\
\text { Tartary }\end{array}$ & $3.80 \pm 0.24 a$ & ND & ND & ND & ND & $7.87 \pm 0.07 b$ & $0.07 \pm 0.00 \mathrm{a}$ & $\begin{array}{c}11.74 \pm \\
0.17 \mathrm{~b}\end{array}$ \\
\hline & & & Xiqiao No.2 & $2.42 \pm 0.80 \mathrm{a}$ & ND & ND & ND & ND & $3.60 \pm 0.92 c$ & $0.05 \pm 0.00 \mathrm{a}$ & $\begin{array}{c}6.06 \pm \\
1.72 \mathrm{c}\end{array}$ \\
\hline & & & Hokkai T10 & $3.89 \pm 0.10 \mathrm{a}$ & ND & ND & ND & ND & $11.99 \pm 0.55 \mathrm{a}$ & $0.17 \pm 0.21 \mathrm{a}$ & $\begin{array}{c}16.04 \pm \\
0.85 \mathrm{a}\end{array}$ \\
\hline & & & $\begin{array}{c}\text { Daegwan } \\
\text { No.3-3 }\end{array}$ & $2.49 \pm 0.48 \mathrm{a}$ & ND & ND & ND & ND & $7.24 \pm 0.19 b$ & $0.07 \pm 0.03 a$ & $\begin{array}{l}9.81 \pm \\
0.64 \mathrm{bc}\end{array}$ \\
\hline \multirow[t]{2}{*}{ Common } & Stem & 72 & Kitawase & $0.32 \pm 0.09$ & ND & ND & ND & $0.45 \pm 0.23$ & $3.80 \pm 2.33$ & $0.08 \pm 0.08$ & $4.64 \pm 2.73$ \\
\hline & & & Dawon & $0.23 \pm 0.30$ & ND & ND & ND & $0.54 \pm 0.06$ & $5.22 \pm 1.38$ & $0.07 \pm 0.10$ & $6.05 \pm 1.72$ \\
\hline \multirow[t]{4}{*}{ Tartary } & & & $\begin{array}{c}\text { Rice } \\
\text { Tartary }\end{array}$ & $1.33 \pm 0.83 a$ & ND & ND & ND & ND & $9.67 \pm 3.02 \mathrm{a}$ & ND & $\begin{array}{c}10.99 \pm \\
3.85 \mathrm{a}\end{array}$ \\
\hline & & & Xiqiao No.2 & $0.58 \pm 0.18 \mathrm{a}$ & ND & ND & ND & ND & $4.25 \pm 0.03 a$ & $0.03 \pm 0.00 \mathrm{a}$ & $\begin{array}{c}4.85 \pm \\
0.19 \mathrm{a}\end{array}$ \\
\hline & & & Hokkai T10 & $0.99 \pm 0.11 \mathrm{a}$ & ND & ND & ND & ND & $9.20 \pm 0.30 \mathrm{a}$ & $0.01 \pm 0.00 \mathrm{a}$ & $\begin{array}{c}10.19 \pm \\
0.18 \mathrm{a}\end{array}$ \\
\hline & & & $\begin{array}{c}\text { Daegwan } \\
\text { No.3-3 }\end{array}$ & $0.69 \pm 0.06 \mathrm{a}$ & ND & ND & ND & ND & $5.75 \pm 0.75 a$ & $0.03 \pm 0.01 \mathrm{a}$ & $\begin{array}{c}6.47 \pm \\
0.81 \mathrm{a}\end{array}$ \\
\hline
\end{tabular}

${ }^{\mathrm{a}}$ Within each column, values followed by the same letters are not significantly different at $P \leq 0.05$, using Tukey's multiple range test ( $\left.n=2\right)$; ${ }^{b} \mathrm{DAS}$; Days after sowing; ' not performed Tukey's multiple range test because there are fewer than three groups; ${ }^{\mathrm{d}} \mathrm{ND}$., not detected; ${ }^{\mathrm{e}} n=1$; no application of the Tukey's multiple range test.

National University in 2011.

\section{REFERENCES}

[1] Holasova, M., Fiedlerova, V., Smrcinova, H., Orsak, M., Lachman, J. and Vavreinova, S. (2002) Buckwheat-The source of antioxidant activity in functional foods. Food Research International, 35, 207-211. http://dx.doi.org/10.1016/S0963-9969(01)00185-5

[2] Kayashita, J., Shimaoka, I. and Nakajyoh, M. (1995) Hypocholesterolemic effect of buckwheat protein extract in rats fed cholesterol enriched diets. Nutrition Research, 15, 691-698. http://dx.doi.org/10.1016/0271-5317(95)00036-I

[3] Tomotake, H., Shimaoka, I., Kayashita, J., Yokoyama, F., Nakajoh, M. and Kato, N.A. (2000) Buckwheat protein product suppresses gallstone formation and plasma cholesterol more strongly than soy protein isolate in hamsters. Journal of Nutrition, 130, 1670-1674.

[4] Aliaga, C. and Lissi, E.A. (2004) Comparison of the free radical scavenger activities of quercetin and rutin-An experimental and theoretical study. Canadian Journal of Chemistry, 82, 1668-1673. http://dx.doi.org/10.1139/v04-151

[5] Li, S.Q. and Zhang, Q.H. (2001) Advances in the development of functional foods from buckwheat. Critical Reviews in Food Science and Nutrition, 41, 451-464. http://dx.doi.org/10.1080/20014091091887

[6] Morishita, T., Yamaguchi, H. and Degi, K. (2007) The contribution of polyphenols to antioxidative activity in common buckwheat and tartary buckwheat grain. Plant Production Science, 10, 99-104. http://dx.doi.org/10.1626/pps.10.99
[7] Fabjan, N., Rode, J., Kosir, I.J., Zang, Z. and Kreft, I. (2003) Tartary buckwheat (Fagopyrum tartaricum Gaertn.) as a source of dietary rutin and quercetrin. Journal of $\mathrm{Ag}$ ricultural and Food Chemistry, 51, 6452-6455. http://dx.doi.org/10.1021/jf034543e

[8] Liu, C.L., Chen, Y.S., Yang, J.H. and Chiang, B.H. (2008) Antioxidant activity of tartary (Fagopyrum tataricum (L.) Gaertn.) and common (Fagopyrum tataricum Gaertn). Buckwheat sprouts. Journal of Agricultural and Food Chemistry, 56, 173-178. http://dx.doi.org/10.1021/jf072347s

[9] Jackson, S.J. and Venema, R.C. (2006) Quercetin inhibits eNOS, microtubule polymerization, and mitotic progresssion in bovine aortic endothelial cells. Journal of Nutrition, 136, 1178-1184.

[10] Edwards, R.L., Lyon, T., Litwin, S.E., Rabovsky, A., Symons, J.D. and Jalili, T. (2007) Quercetin reduces blood pressure in hypertensive subjects. Journal of Nutrition, 137, 2405-2411.

[11] Kim S.J., Zaidul, I.S.M., Suzuki, T., Mukasa, Y., Hashimoto, N., Takigawa, S., Noda, T., Chie, M.E. and Yamauchi, H. (2008) Comparison of phenolic compositions between common and tartary buckwheat (Fagopyrum) sprouts. Food Chemistry, 110, 814-820. http://dx.doi.org/10.1016/j.foodchem.2008.02.050

[12] Szostak, D.D. (2004) Flavonoids in hulls of different varieties of buckwheat and their antioxidant activity. Proceedings of the 9th International Symposium on Buckwheat, Prague, 18-22 August 2004, 621-625.

[13] Kim J.H., Lee B.C., Kim J.H., Sim G.S., Lee D.H., Lee K.E., Yun Y.P. and Pyo H.B. (2005) The isolation and antioxidative effects of vitexin from Acerpalmatum. Archives of Pharmacal Research, 28, 195-202. 
http://dx.doi.org/10.1007/BF02977715

[14] Devi P.U., Ganasaundari, A., Vrinda, B., Srinivasan, K.K. and Unnikrishnan, M.K. (2000) Radiation protection by the Ocimum flavonoids orientin and vicenin: Mechanism of action. Radiation Research, 154, 455-460. http://dx.doi.org/10.1667/0033-7587(2000)154[0455:RP BTOF]2.0.CO;2

[15] Amimoto, K., Yamazaki, A., Tokoro, K., Kudo, R. and Fukui, H. (1996) The ingredient analysis of vegetables for the purpose of chemical development. (The first report)Comparison between the kinds of the lettuce ingredient (in Japanese). J-STAGE, 8, 146-153. http://dx.doi.org/10.2525/jshita.8.146

[16] Sharma, P. and Gujral, H.S. (2010) Antioxidant and polyphenol oxidase activity of germinated barley and its milling fractions. Food Chemistry, 120, 673-678. http://dx.doi.org/10.1016/i.foodchem.2009.10.059

[17] Tian, S., Nakamura, K. and Kayahara, H. (2004) Analysis of phenolic compounds in white rice, brown rice, and germinated brown rice. Journal of Agricultural and Food Chemistry, 52, 4808-4813. http://dx.doi.org/10.1021/jf049446f

[18] Cho S.Y., Lee Y.N. and Park, H.J. (2009) Optimization of ethanol extraction and further purification of isoflavones from soybean sprout cotyledon. Food Chemistry, 117, 312-317.

http://dx.doi.org/10.1016/j.foodchem.2009.04.003

[19] Kim E.H., Kim S.H., Chung J.I., Chi H.Y., Kim J.A. and Chung, I.M. (2006) Analysis of phenolic compounds and isoflavones in soybean seeds (Glycine $\max (\mathrm{L}$.$) Merill)$ and sprouts grown under different conditions. European
Food Research and Technology, 222, 201-208. http://dx.doi.org/10.1007/s00217-005-0153-4

[20] Duenas, M., Hernandez, T., Estrella, I. and Fernandez, D. (2009) Germination as a process to increase the polyphenol content and antioxidant activity of lupin seeds ( $\mathrm{Lu}$ pinus angustifolius L.). Food Chemistry, 117, 599-607. http://dx.doi.org/10.1016/j.foodchem.2009.04.051

[21] Zielinski, H., Honke, J., Łatosz, A., Troszyńska, A., Ciska, E., Waszczuk, K., Szawara-Nowak, D. and Kozłowska, H. (1998) A rapid method for measurement of total antioxidant status of selected cereal grains-short report. Polish Journal of Food and Nutrition Sciences, 7, 533-538.

[22] Zielinski, H. and Troszyńska, A. (2000) Antioxidant capacity of raw and hydrothermal processed cereal grains. Polish Journal of Food and Nutrition Sciences, 9/50, 7983.

[23] Tahir, I. and Farooq, S. (1985) Grain composition in some buckwheat cultivars (Fagopyrum Spp.) with particular reference to protein fractions. Plant Foods for Human Nutrition, 35, 153-158. http://dx.doi.org/10.1007/BF01092131

[24] Oomah, B.D. and Mazza, G. (1996) Flavonoids and antioxidative activities in buckwheat. Journal of Agricultural and Food Chemistry, 44, 1746-1750. http://dx.doi.org/10.1021/jf9508357

[25] Park B.J., Park J.I., Chang K.J. and Park, C.H. (2004) Comparison in rutin content in seed and plant of tartary buckwheat (Fagopyrum tartaricum). Proceedings of the 9th International Symposium on Buckwheat, Prague, 1822 August 2004, 626-629. 